\title{
PREPARATION OF A LIGNIN-BASED COMPOSITE AND ITS PROPERTIES
}

\author{
Jian Li, Shujun Li,* Haigang Wang, Yang Yang, and Guowan Guo
}

Enzymatic hydrolysis (EH) lignin was modified with formaldehyde. TGDSC and PY-GC-MS analysis methods were adopted to characterize the differences between $\mathrm{EH}$ lignin and the modified lignin. The modified lignin was then mixed with wood sawdust and made into a lignin-based composite under the following conditions: pressure of 2 to $5 \mathrm{MPa}$, temperature of 175 to $190{ }^{\circ} \mathrm{C}$, and the modified lignin dosage of $20 \%$ to $70 \%$. The effects of pressure, temperature, and the modified lignin dosage on the properties of the composites were also evaluated. The pressure of $2 \mathrm{MPa}$ was not enough to make a strong composite, and the composite with low dosage of modified lignin could not resist water, which signifies pressure and the ratio of modified lignin to sawdust are vital factors. Temperatures of $175{ }^{\circ} \mathrm{C}$ and $190{ }^{\circ} \mathrm{C}$ did not make much difference to change the mechanical properties of the composites. The composites which were made under $3 \mathrm{MPa}, 180{ }^{\circ} \mathrm{C}$, and the ratio of $1: 1$ modified lignin to wood sawdust was of fair quality. The samples made with the modified lignin dosage of $70 \%$ under $2 \mathrm{MPa}$ at $180{ }^{\circ} \mathrm{C}$ for $10 \mathrm{~min}$ showed a low thickness swelling and low rates of water absorption from humid air and liquid water. Their free formaldehyde contents were also low and met Grade 2 in the national standard of China.

Keywords: Lignin; Modification; Phenolic hydroxyl groups; Composite; Properties

Contact information: Key Laboratory of Biobased Material Science and Technology of Ministry of Education, Northeast Forestry University, Harbin, Heilongjiang 150040 P.R. China; * Corresponding author: lishujun_1999@yahoo.com

\section{INTRODUCTION}

Recently the fuel ethanol industry, which takes renewable plant resources as its raw materials, has been developing rapidly. In its process, carbohydrates are biodegraded and fermented, then ethanol is produced. However, large amounts of enzymatic hydrolyzed lignin (EH lignin) residue is also produced while the carbohydrates are being converted into ethanol. Such EH lignin can be considered to be a waste product from this fuel ethanol industry and could cause environment pollution, in a similar manner to the lignin from the pulping and paper making industry (Zaldivar et al. 2001; Galbe and Zacchi 2002; Sun and Cheng 2002; Hahn-Hägerdal et al. 2006; Demirbas 2007; Öhgren et al. 2007).

Lignin is a biodegradable resource, and there are phenolic hydroxyl, aldehyde, carboxyl, and other functional groups in its molecular structure (Sjöström 1993). Compared with those pulping processes, the process conditions during enzymatic reactions are very moderate. As a consequence, phenolic hydroxyl and other active groups in EH lignin could be well preserved (Kleinert and Barth 2008; Yang 2006). EH 
lignin should be suitable for many uses. Although there have been many studies on utilization of EH lignin, most of studies are not feasible for industrialization because $\mathrm{EH}$ lignin has to be refined in many steps (Cheng and Jin 2008; Zhou et al. 2009). This resource has not been utilized efficiently.

Meanwhile, the processing cost of the fuel ethanol industry is so high that it is not easy to make profits. Until now, most factories in this industry of China could not survive without subsidization from our government. If EH lignin could be applied to make some products, it would be very helpful for the factories to make profits.

In recent years, many studies have attempted to use modified lignin in place of phenol (Alonso et al. 2001). Malutan and others studied the hydroxymethylation of alkali lignin with formaldehyde in alkaline solution (Malutan et al. 2008a) and further epoxidation (Malutan et al. 2008b). Considering the presence of many active phenolic groups in EH lignin, it was modified to make EH lignin composites. Both the process and the product properties were evaluated in this study.

\section{EXPERIMENTAL}

\section{Materials}

Lumping EH lignin was offered by COFCO Biochemical Energy (Zhaodong) Co., LTD. After being smashed and screened, the material smaller than 60 mesh was used for preparing EH lignin composites. Other chemicals were reagents of analytical grade. Waste hardwood sawdust was ground and sieved. The material smaller than 60 mesh was used.

\section{Methods}

Chemical component analysis of EH lignin

The EH lignin was not pure, and its complicate components would be expected to affect the conditions of preparing of $\mathrm{EH}$ lignin composites to some extent. So the content of its chemical components were determined according to national standard methods. Its phenol content was analyzed with the FC method (Lai et al. 2007). The reaction products of the Folin-Ciocalteau (FC) reducing agent (made by Sigma) and phenols have a blue color that exhibits a broad light absorption with a maximum at $765 \mathrm{~nm}$. The intensity of light absorption at that wavelength is proportional to the concentration of phenols.

\section{Modification of EH lignin}

There are some free phenolic groups in EH lignin, so the material could be modified by formaldehyde, and a sticky substance similar to PF resin was synthesized according to the reference (Li and Bai 1997). Modification of EH lignin was conducted in a dry flask with an electronic stirrer, a thermometer, and a condenser. $25 \mathrm{~g}$ EH lignin was mixed with $100 \mathrm{~mL}$ water and $0.34 \mathrm{~g} \mathrm{NaOH}$, with gentle heating and stirring. Then the mixture was heated up to 65 to $80{ }^{\circ} \mathrm{C}$, and formaldehyde was added dropwise until its molar ratio to phenol reached 1:1, and the reaction mixture was stirred for another $2 \mathrm{~h}$.

To check the difference between the original EH lignin and the modified lignin, both of the original EH lignin and the modified lignin were characterized by thermoanal- 
ytical measurements. Low molecular weight compounds released during pyrolysis were analyzed. The thermoanalytical measurements were obtained with a NETZSCH STA 409 PC/PG with a DSC/TG sample carrier, and $10 \mathrm{mg}$ of extra-dried each sample was heated up from room temperature to $1200{ }^{\circ} \mathrm{C}$ at a rate of $4{ }^{\circ} \mathrm{C} / \mathrm{min}$ under $\mathrm{N} 2 / 30 / \mathrm{N} 2 / 20$.

PY-GC-MS analysis was performed to analyze the low molecular weight compounds released during the pyrolysis. The analysis was performed with a coupling instrument of Pyrojector II (made by SGE, AU) and GC-MS 6890N-5973 insert (made by Agilent, USA). The information on released substances during pyrolysis could be collected. The pyrolysis temperature was $600{ }^{\circ} \mathrm{C}$. For the GC part, its capillary column was DB-17MS with a length of $30 \mathrm{~m}$, the inner diameter of $0.25 \mathrm{~mm}$, and a membrane thickness of $0.25 \mathrm{um}$. The injector temperature was $260{ }^{\circ} \mathrm{C}$. The carrier gas was helium and its flow rate was $1 \mathrm{~mL} / \mathrm{min}$, splitless. The initial column temperature was $40^{\circ} \mathrm{C}$, and it was kept for $3 \mathrm{~min}$. Then the column was heated up to $250{ }^{\circ} \mathrm{C}$ at the rate of $5{ }^{\circ} \mathrm{C} / \mathrm{min}$ and kept for $5 \mathrm{~min}$. The GC-MS interface temperature was $280^{\circ} \mathrm{C}$. The electron energy of EI source was $70 \mathrm{eV}$, and the ion source temperature was $230^{\circ} \mathrm{C}$. MS conditions for analysis were: scan range of 15 to $360 \mathrm{amu}$.

\section{Preparing of lignin-based composites}

A Siempelkamp FTR250 atomizing resin blender was used to mix the modified lignin and wood sawdust. After being air-dried, $125 \mathrm{~g}$ of the mixture was hot-pressed into $500 \mathrm{~mm}$ by $500 \mathrm{~mm}$ boards. Their thickness was controlled to around $5 \mathrm{~mm}$. Each group of conditions was replicated on 6 composites. In this study, the modified lignin was mixed with the waste hardwood sawdust and a lignin-based composite was prepared under the following conditions: pressure of 2 to $5 \mathrm{MPa}$, temperature of 175 to $190{ }^{\circ} \mathrm{C}$, and the dosage of $20 \%$ to $70 \%$ modified lignin in the composites. All the composites were hot-pressed for about $10 \mathrm{~min}$, which is long enough to solidify all the modified lignin in the composites. The tests of bending strength and elastic modulus were conducted with $100 \mathrm{~mm} \times 50 \mathrm{~mm}$ specimens under a span of $100 \mathrm{~mm}$, a fixed flexure of $0.5 \mathrm{~mm}$ and a crosshead speed of $2.0 \mathrm{~mm} / \mathrm{min}$. Thickness swelling rate due to moisture absorption of the products from humid air was tested with $50 \mathrm{~mm} \times 50 \mathrm{~mm}$ specimens under $20 \pm 2{ }^{\circ} \mathrm{C}$ and $\mathrm{RH}(65 \pm 5 \%$. Then the specimens were vertically sunk in the water of $\mathrm{pH} 7$ at the same temperature for a certain time to calculate thickness swelling rate in the case of liquid water absorption. Free formaldehyde content was measured using the desiccator method with $150 \mathrm{~mm} \times 50 \mathrm{~mm}$ specimens. The influence of pressure, temperature, and the ratio of modified lignin to sawdust was evaluated.

\section{RESULTS AND DISCUSSION}

\section{Components of the EH Lignin}

Some component contents of the EH lignin are shown in Table 1. Its acidinsoluble lignin content was $65.64 \%$, and acid soluble lignin content was $4.82 \%$. This acid-soluble lignin content signifies that there were a few low molecular weight lignin components in the material. Total lignin accounted for $70.46 \%$ of the EH lignin. During the process of converting cellulose and hemi-cellulose into fuel ethanol by enzyme, the 
carbohydrate could not be consumed totally. The carbohydrates and other acid-soluble substance took up about $30 \%$ of the EH lignin. The phenolic hydroxyl group content of the EH lignin was $2.489 \times 10^{-3} \mathrm{~mol} / \mathrm{g}$. Although this phenolic hydroxyl group content is much lower than that of phenol $\left(1.063 \times 10^{-2} \mathrm{~mol} / \mathrm{g}\right)$, it implies that this material was active and it could be helpful for bonding materials after being modified.

Table 1. Component Contents of the EH Lignin, Including Moisture

\begin{tabular}{|c|c|c|c|c|}
\hline $\begin{array}{c}\text { Moisture } \\
(\%)\end{array}$ & $\begin{array}{c}\text { Ash } \\
(\%)\end{array}$ & $\begin{array}{c}\text { Acid insoluble } \\
\text { lignin (\%) }\end{array}$ & $\begin{array}{c}\text { Acid soluble } \\
\text { lignin (\%) }\end{array}$ & $\begin{array}{c}\text { Phenolic hydroxyl } \\
\text { groups (mol/g) }\end{array}$ \\
\hline 5.43 & 9.91 & 65.64 & 4.82 & $2.489 \times 10^{-3}$ \\
\hline
\end{tabular}

\section{TG-DSC Analysis}

Both EH lignin and modified lignin were analyzed by TG-DSC. Their data of quick weight losses were recorded, and results are shown in Fig. 1 and Table 2.

Table 2. Data of the Quick Weight Losses

\begin{tabular}{|c|c|c|c|c|c|}
\hline Sample & $\begin{array}{c}\text { Initiation } \\
\text { temperature }\left({ }^{\circ} \mathrm{C}\right)\end{array}$ & $\begin{array}{c}\text { Middle } \\
\text { temperature }\left({ }^{\circ} \mathrm{C}\right)\end{array}$ & $\begin{array}{c}\text { Point of } \\
\text { Inflection }\left({ }^{\circ} \mathrm{C}\right)\end{array}$ & $\begin{array}{c}\text { End point } \\
\left({ }^{\circ} \mathrm{C}\right)\end{array}$ & $\begin{array}{c}\text { Weight } \\
\text { loss }\left({ }^{\circ} \mathrm{C}\right)\end{array}$ \\
\hline EH lignin & 292.3 & 334.6 & 345.0 & 376.9 & 46.48 \\
\hline Modified lignin & 278.8 & 332.0 & 334.5 & 384.7 & 46.60 \\
\hline
\end{tabular}

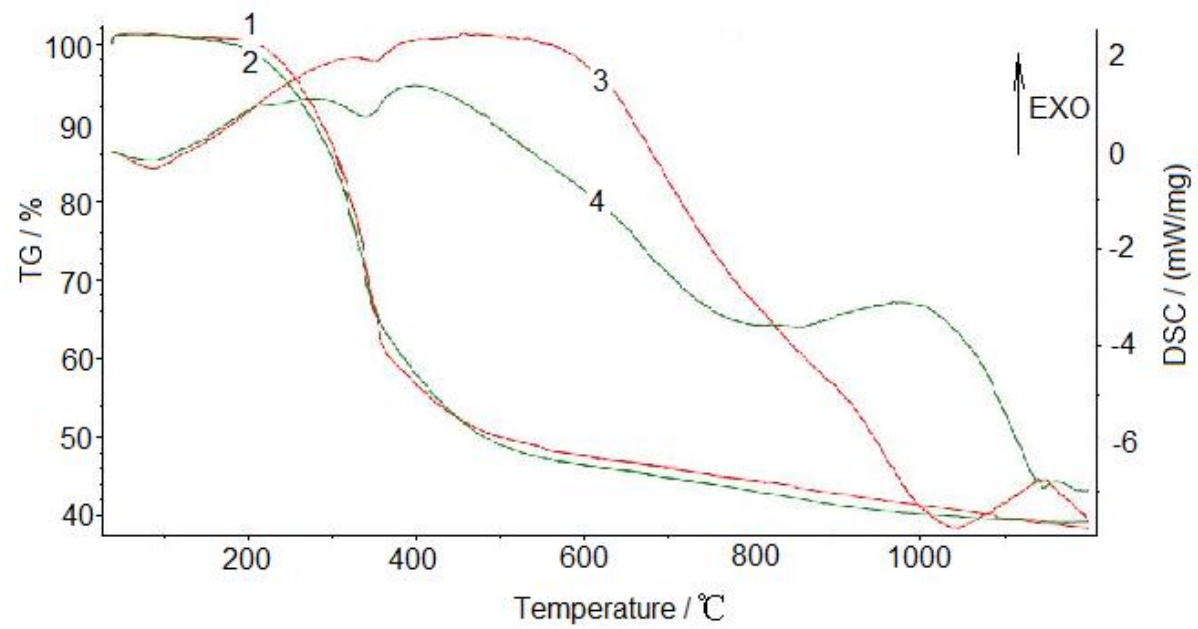

Fig. 1. TG and DSC curves of EH lignin and its modified lignin (1-TG curve of EH lignin, 2-TG curve of modified lignin, 3-DSC curve of EH lignin, 4-DSC curve of modified lignin)

According to Table 2 and Fig. 1, the modified lignin had an earlier initiation temperature, an earlier point of inflection, and a later end point. It also had a little bigger weight loss, because the modification increased the level of hydroxymethyl groups, which are easily pyrolyzed. From Fig. 1, TG curves of EH lignin and the modified lignin were similar, but there were some differences between DSC curves, which indicates that the modification did change the $\mathrm{EH}$ lignin. Around $400{ }^{\circ} \mathrm{C}$ the modified lignin released less heat than $\mathrm{EH}$ lignin did, because its resination reaction consumed some heat. At 1000 ${ }^{\circ} \mathrm{C}$ or so, EH lignin took more heat to pyrolyze than the modified lignin did. 


\section{PY-GC-MS Analysis}

$\mathrm{EH}$ lignin and the modified lignin were analyzed by PY-GC-MS, and some information on the released substance was collected. Results are shown in Fig. 2, Table 3, Fig. 3, and Table 4.

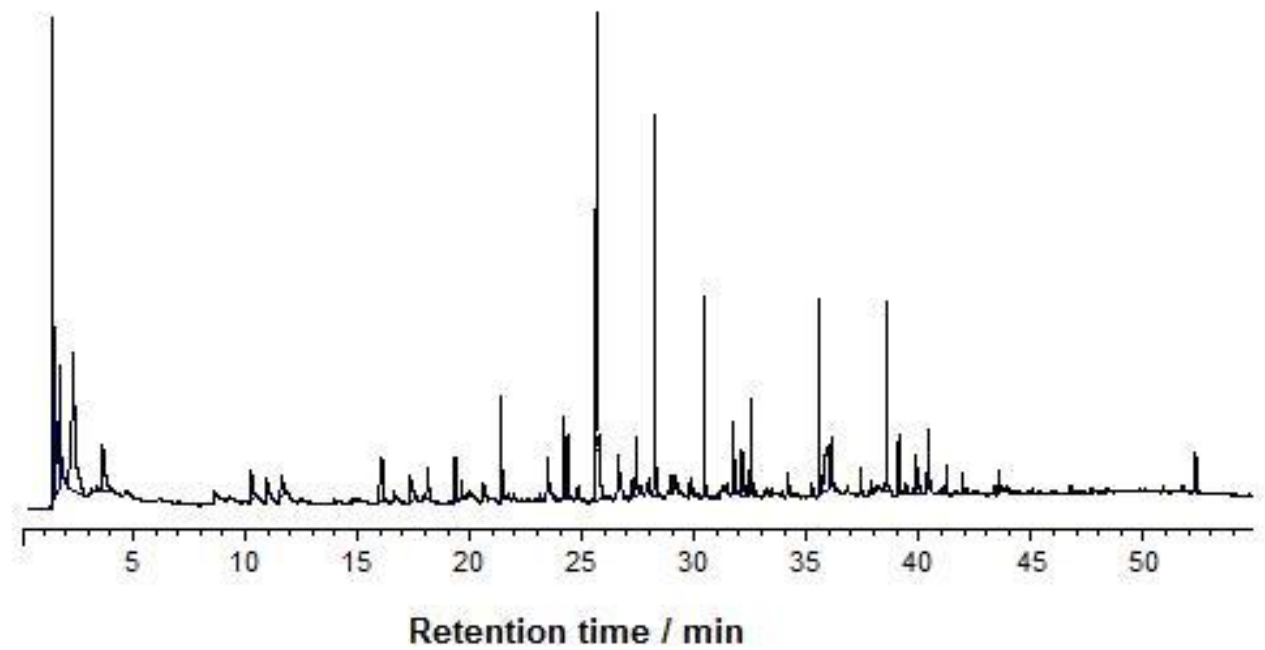

Fig. 2. Gas chromatographic (GC) spectrum of the released substances from EH lignin pyrolysis

Table 3. Some Compounds Released during the Pyrolysis of EH Lignin

\begin{tabular}{|c|c|c|c|c|c|}
\hline No. & $\begin{array}{c}\text { Retention } \\
\text { time (min) }\end{array}$ & Compound name & Formula & $\begin{array}{c}\text { Content } \\
(\%)\end{array}$ & $\begin{array}{c}\text { Confidence } \\
(\%)\end{array}$ \\
\hline 1 & 11.628 & Styrene & $\mathrm{C}_{8} \mathrm{H}_{8}$ & 0.605 & 97 \\
\hline 2 & 16.073 & 1,2-Cyclopentanedione & $\mathrm{C}_{5} \mathrm{H}_{6} \mathrm{O}_{2}$ & 2.053 & 87 \\
\hline 3 & 17.356 & Phenol & $\mathrm{C}_{6} \mathrm{H}_{6} \mathrm{O}$ & 1.729 & 95 \\
\hline 4 & 18.108 & $2(5 \mathrm{H})$-Furanone & $\mathrm{C}_{4} \mathrm{H}_{4} \mathrm{O}_{2}$ & 1.231 & 90 \\
\hline 5 & 21.408 & Phenol, 2-methoxy- & $\mathrm{C}_{7} \mathrm{H}_{8} \mathrm{O}_{2}$ & 2.194 & 97 \\
\hline 6 & 23.452 & Phenol, 4-ethyl- & $\mathrm{C}_{8} \mathrm{H}_{10} \mathrm{O}$ & 0.467 & 91 \\
\hline 7 & 24.358 & Phenol, 2-methoxy-4-methyl- & $\mathrm{C}_{8} \mathrm{H}_{10} \mathrm{O}_{2}$ & 1.460 & 95 \\
\hline 8 & 25.666 & Benzofuran, 2,3-dihydro- & $\mathrm{C}_{8} \mathrm{H}_{8} \mathrm{O}$ & 20.007 & 87 \\
\hline 9 & 27.410 & 1,2-Benzenediol, 3-methoxy- & $\mathrm{C}_{7} \mathrm{H}_{8} \mathrm{O}_{3}$ & 1.348 & 93 \\
\hline 10 & 28.265 & 2-Methoxy-4-vinylphenol & $\mathrm{C}_{9} \mathrm{H}_{10} \mathrm{O}_{2}$ & 8.288 & 90 \\
\hline 11 & 30.454 & Phenol, 2,6-dimethoxy- & $\mathrm{C}_{8} \mathrm{H}_{10} \mathrm{O}_{3}$ & 3.556 & 96 \\
\hline 12 & 31.754 & Phenol, 2-methoxy-4-(1-propenyl)-, & $\mathrm{C}_{10} \mathrm{H}_{12} \mathrm{O}_{2}$ & 1.259 & 98 \\
\hline 13 & 32.121 & (E)- & & & \\
\hline 14 & 32.515 & Benzoic acid, 4-hydroxy-3-methoxy- & $\mathrm{C}_{8} \mathrm{C}_{8} \mathrm{O}_{3} \mathrm{H}_{8} \mathrm{O}_{4}$ & 1.000 & 96 \\
\hline 15 & 35.952 & D-Allose & $\mathrm{C}_{6} \mathrm{H}_{12} \mathrm{O}_{6}$ & 3.559 & 87 \\
\hline 16 & 36.088 & Phenol, 2,6-dimethoxy-4-(2-propenyl)- & $\mathrm{C}_{11} \mathrm{H}_{14} \mathrm{O}_{3}$ & 1.137 & 90 \\
\hline 17 & 37.405 & Phenol, 2,6-dimethoxy-4-(2-propenyl)- & $\mathrm{C}_{11} \mathrm{H}_{14} \mathrm{O}_{3}$ & 0.439 & 94 \\
\hline 18 & 38.576 & Phenol, 2,6-dimethoxy-4-(2-propenyl)- & $\mathrm{C}_{11} \mathrm{H}_{14} \mathrm{O}_{3}$ & 3.538 & 94 \\
\hline 19 & 39.081 & Benzaldehyde, 4-hydroxy-3,5- & $\mathrm{C}_{9} \mathrm{H}_{10} \mathrm{O}_{4}$ & 0.856 & 94 \\
\hline 20 & 39.919 & dimethoxy- & & & \\
\hline 21 & 40.423 & Ethanone, 1-(4-hydroxy-3,5- & $\mathrm{C}_{10} \mathrm{H}_{12} \mathrm{O}_{4}$ & 0.983 & 94 \\
\hline & & dimethoxyphenyl)- & & \\
\hline
\end{tabular}


Figure 2 is the GC spectrum of the released substances during the pyrolysis of EH lignin. Some compounds during the pyrolysis of EH lignin were observed to be present with more than $80 \%$ confidence, and their contents are given in Table 3 . According to the data, many kinds of phenolics released during the pyrolysis of $\mathrm{EH}$ lignin and totally phenolic content took up $29.18 \%$ of all released substance. These phenolics could be collected and recycled.

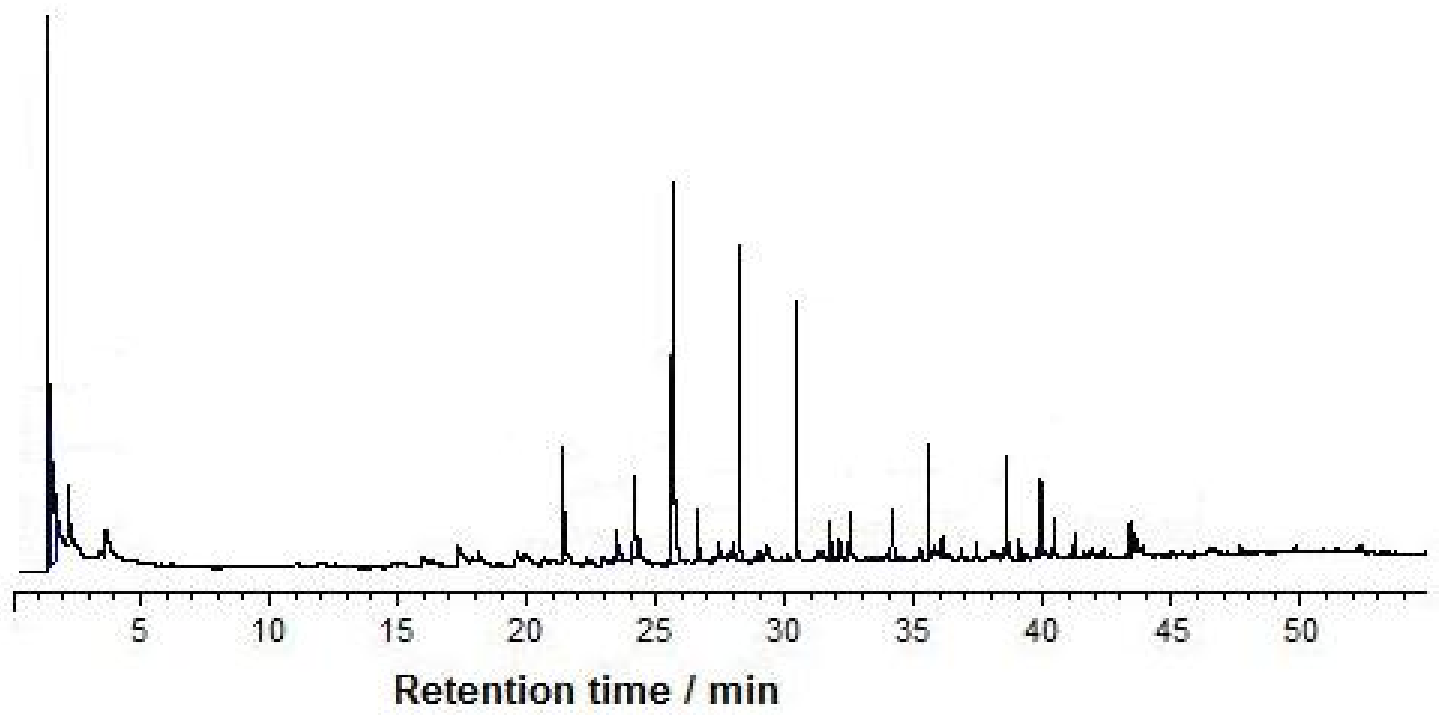

Fig. 3. GC spectrum of the released substances during the pyrolysis of the modified lignin

Table 4. Some Compounds Released during Pyrolysis of the Modified Lignin

\begin{tabular}{|c|c|c|c|c|c|}
\hline $\begin{array}{c}\text { Peak } \\
\text { No. }\end{array}$ & $\begin{array}{c}\text { Retention } \\
\text { time (min) }\end{array}$ & Compound name & Formula & $\begin{array}{c}\text { Content } \\
(\%)\end{array}$ & $\begin{array}{c}\text { Confidence } \\
(\%)\end{array}$ \\
\hline 1 & 2.257 & Acetic acid & $\mathrm{C}_{2} \mathrm{H}_{4} \mathrm{O}_{2}$ & 2.925 & 86 \\
\hline 2 & 21.409 & Phenol, 2-methoxy- & $\mathrm{C}_{7} \mathrm{H}_{8} \mathrm{O}_{2}$ & 4.850 & 97 \\
\hline 3 & 23.486 & Phenol, 4-ethyl- & $\mathrm{C}_{8} \mathrm{H}_{10} \mathrm{O}$ & 2.200 & 91 \\
\hline 4 & 26.632 & Phenol, 4-ethyl-2-methoxy- & $\mathrm{C}_{9} \mathrm{H}_{12} \mathrm{O}_{2}$ & 2.124 & 90 \\
\hline 5 & 28.240 & 2-Methoxy-4-vinylphenol & $\mathrm{C}_{9} \mathrm{H}_{10} \mathrm{O}_{2}$ & 9.158 & 90 \\
\hline 6 & 30.454 & Phenol, 2,6-dimethoxy- & $\mathrm{C}_{8} \mathrm{H}_{10} \mathrm{O}_{3}$ & 7.309 & 96 \\
\hline 7 & 31.754 & $\begin{array}{c}\text { Phenol, 2-methoxy-4-(1- } \\
\text { propenyl)-, (E)- }\end{array}$ & $\mathrm{C}_{10} \mathrm{H}_{12} \mathrm{O}_{2}$ & 1.231 & 98 \\
\hline 8 & 32.506 & $\begin{array}{c}\text { Benzoic acid, 4-hydroxy-3- } \\
\text { methoxy- }\end{array}$ & $\mathrm{C}_{8} \mathrm{H}_{8} \mathrm{O}_{4}$ & 0.947 & 87 \\
\hline 9 & 38.568 & $\begin{array}{c}\text { Phenol, 2,6-dimethoxy-4-(2- } \\
\text { propenyl)- }\end{array}$ & $\mathrm{C}_{11} \mathrm{H}_{14} \mathrm{O}_{3}$ & 2.500 & 94 \\
\hline 10 & 39.825 & Hexadecanoic acid, ethyl ester & $\mathrm{C}_{18} \mathrm{H}_{36} \mathrm{O}_{2}$ & 0.921 & 99 \\
\hline 11 & 39.910 & n-Hexadecanoic acid & $\mathrm{C}_{16} \mathrm{H}_{32} \mathrm{O}_{2}$ & 1.585 & 99 \\
\hline 12 & 40.415 & $\begin{array}{c}\text { Ethanone, 1-(4-hydroxy-3,5- } \\
\text { dimethoxyphenyl)- }\end{array}$ & $\mathrm{C}_{10} \mathrm{H}_{12} \mathrm{O}_{4}$ & 1.292 & 96 \\
\hline 13 & 43.407 & Octadecanoic acid, ethyl ester & $\mathrm{C}_{20} \mathrm{H}_{40} \mathrm{O}_{2}$ & 0.970 & 89 \\
\hline
\end{tabular}


Figure 3 is a GC spectrum of the released substances during the pyrolysis of the modified lignin. Some compounds during the pyrolysis of modified lignin were present with more than $80 \%$ confidence, and their contents are given in Table 4 . According to the data, the kinds of phenolics released during the pyrolysis of modified lignin were similar to those from EH lignin. Totally phenolic content took up $31.61 \%$ of all released substance from modified lignin. This finding was also similar with that for EH lignin.

\section{Mechanical Properties of the Lignin Composites}

The modified lignin was mixed with wood sawdust, and lignin-based composites were made under the following conditions: temperature of 175 to $190{ }^{\circ} \mathrm{C}$, a modified lignin dosage of $20 \%$ to $70 \%$, and a pressure of 2 to $5 \mathrm{MPa}$. The effects of temperature, modified lignin dosage, and pressure on the properties of the composites were also evaluated.

Table 5 shows the effect of temperature on the mechanical properties of the composites. These composites were made at pressing temperature of from $175{ }^{\circ} \mathrm{C}$ to 180 ${ }^{\circ} \mathrm{C}$, EH lignin dosage of $20 \%$, hot-pressing pressure of $2.0 \mathrm{MPa}$, and pressing time of 10 min. According to Table 5, the mechanical properties of the composites were all not good, and there was no big difference between them. Among them, the composites made at $180{ }^{\circ} \mathrm{C}$ had the best mechanical properties. Its maximum load was only $32.6 \mathrm{~N}$, and its bending strength was only $3.455 \mathrm{MPa}$.

Table 5. Effect of Temperature on the Mechanical Properties of the Products

\begin{tabular}{|c|c|c|c|}
\hline $\begin{array}{c}\text { Temperature } \\
\left({ }^{\circ} \mathrm{C}\right)\end{array}$ & $\begin{array}{c}\text { Max. load } \\
(\mathrm{N})\end{array}$ & $\begin{array}{c}\text { Bending strength } \\
(\mathrm{MPa})\end{array}$ & $\begin{array}{c}\text { Elastic modulus } \\
(\mathrm{GPa})\end{array}$ \\
\hline 175 & 23 & 2.482 & 0.68 \\
\hline 180 & 32.6 & 3.455 & 0.565 \\
\hline 185 & 27 & 3.022 & 0.452 \\
\hline 190 & 24.8 & 2.519 & 0.318 \\
\hline
\end{tabular}

Table 6 shows the effect of the modified lignin dosage on the mechanical properties of the composites. These composites were made at the modified lignin dosage from $20 \%$ to $70 \%$, pressing temperature of $180{ }^{\circ} \mathrm{C}$, hot-pressing pressure of $2.0 \mathrm{MPa}$, and pressing time of $10 \mathrm{~min}$. According to Table 6, the modified lignin dosage of $20 \%$ was too low to make good composites. With the increasing of the modified lignin dosage, the composites had much better mechanical properties. When the modified lignin dosage was $70 \%$, its maximum load was $108.6 \mathrm{~N}$, its bending strength was $22.97 \mathrm{MPa}$, and its elastic modulus was $3.35 \mathrm{GPa}$.

Table 6. Effect of Modified Lignin Dosage on the Mechanical Properties of Composites

\begin{tabular}{|c|c|c|c|}
\hline $\begin{array}{c}\text { Modified lignin dosage } \\
(\%)\end{array}$ & $\begin{array}{c}\text { Max. load } \\
(\mathrm{N})\end{array}$ & $\begin{array}{c}\text { Bending strength } \\
(\mathrm{MPa})\end{array}$ & $\begin{array}{c}\text { Elastic modulus } \\
(\mathrm{GPa})\end{array}$ \\
\hline 20 & 32.6 & 3.455 & 0.57 \\
\hline 30 & 64.4 & 11.23 & 1.01 \\
\hline 40 & 94.2 & 15.69 & 1.59 \\
\hline 50 & 102.95 & 20.09 & 2.6 \\
\hline 70 & 108.6 & 22.97 & 3.35 \\
\hline
\end{tabular}


Table 7 shows the effect of hot-pressing pressure on the mechanical properties of the composites. These composites were made at hot-pressing pressure of $2.0 \mathrm{MPa}$ to 5.0 $\mathrm{MPa}$, the modified lignin dosage of $20 \%$, pressing temperature of $180{ }^{\circ} \mathrm{C}$, and pressing time of $10 \mathrm{~min}$. According to Table 7, the hot-pressing pressure of $2.0 \mathrm{MPa}$ was a little too low to make good composites. With the increasing of the hot-pressing pressure, the composites also had much better mechanical properties. When the pressure was $5.0 \mathrm{M} \mathrm{Pa}$, its maximum load was $156.8 \mathrm{~N}$, its bending strength was $27.62 \mathrm{MPa}$, and its elastic modulus was $4.48 \mathrm{GPa}$.

Table 7. Effect of Pressure on the Mechanical Properties of the Composites

\begin{tabular}{|c|c|c|c|}
\hline $\begin{array}{c}\text { Pressure } \\
(\mathrm{MPa})\end{array}$ & $\begin{array}{c}\text { Max. load } \\
(\mathrm{N})\end{array}$ & $\begin{array}{c}\text { Bending strength } \\
(\mathrm{MPa})\end{array}$ & $\begin{array}{c}\text { Elastic modulus } \\
(\mathrm{GPa})\end{array}$ \\
\hline 2.0 & 102.95 & 20.09 & 2.60 \\
\hline 3.0 & 121 & 23.35 & 3.78 \\
\hline 4.0 & 133.8 & 25.83 & 3.97 \\
\hline 5.0 & 156.8 & 27.62 & 4.48 \\
\hline
\end{tabular}

According to the effects of the three parameters on the mechanical properties of the composites, the dosage of modified lignin was the vital one and the others did not have a big influence. So in the later experiments, only the effects of the modified lignin dosage on the composite properties were determined.

\section{Anti-moisture Ability of the Composites}

These samples were made with the modified lignin dosage levels of $30 \%, 40 \%$, $50 \%$, and $70 \%$ under $2 \mathrm{MPa}$ pressure at $180{ }^{\circ} \mathrm{C}$ for $10 \mathrm{~min}$. After being oven-dried at 103 $\pm 2{ }^{\circ} \mathrm{C}$, they were conditioned at $20 \pm 2{ }^{\circ} \mathrm{C}$ and $\mathrm{RH}(65 \pm 5) \%$ for five days. Their thickness swelling and mass increasing rates of moisture absorption were recorded, and results are shown in Tables 8 and 9. According to the data, the samples had low thickness swelling rates $(0.43 \%$ to $0.69 \%)$, due to low moisture absorption from the humid air, and also low mass increase rates of moisture absorption (around 1.2\%). After 5 days, those samples still had low thickness swelling rates $(2.2 \%$ to $3.0 \%)$ due to moisture absorption and also low mass increasing rates of moisture absorption (3.5\% to $4.4 \%)$.

Table 8. Thickness Swelling Rates due to Moisture Absorption from Air by Different Samples (\%)

\begin{tabular}{|c|c|c|c|c|c|}
\hline $\begin{array}{c}\text { Modified lignin dosage } \\
(\%)\end{array}$ & $1 \mathrm{~d}$ & $2 \mathrm{~d}$ & $3 \mathrm{~d}$ & $4 \mathrm{~d}$ & $5 \mathrm{~d}$ \\
\hline 30 & 0.50 & 0.88 & 1.77 & 2.31 & 2.61 \\
\hline 40 & 0.43 & 0.90 & 1.53 & 1.92 & 2.23 \\
\hline 50 & 0.68 & 1.53 & 1.82 & 2.16 & 2.41 \\
\hline 70 & 0.69 & 1.24 & 1.85 & 2.49 & 2.92 \\
\hline
\end{tabular}


Table 9. Mass Increasing Rates due to Moisture Absorption by from Air by Different Samples (\%)

\begin{tabular}{|c|c|c|c|c|c|}
\hline $\begin{array}{c}\text { Modified lignin dosage } \\
(\%)\end{array}$ & $1 \mathrm{~d}$ & $2 \mathrm{~d}$ & $3 \mathrm{~d}$ & $4 \mathrm{~d}$ & $5 \mathrm{~d}$ \\
\hline 30 & 1.02 & 1.73 & 2.60 & 3.70 & 4.38 \\
\hline 40 & 1.51 & 2.04 & 3.20 & 3.42 & 4.10 \\
\hline 50 & 1.29 & 1.74 & 2.78 & 2.98 & 3.94 \\
\hline 70 & 1.23 & 1.98 & 3.14 & 3.38 & 3.59 \\
\hline
\end{tabular}

\section{Resistance of the Composites to Liquid Water}

These samples were made under the same conditions with those evaluated for anti-moisture ability in the case of humid air. After being conditioned at $20 \pm 2{ }^{\circ} \mathrm{C}$ and $\mathrm{RH}(65 \pm 5) \%$, they were separately hung and soaked in water of $(20 \pm 2){ }^{\circ} \mathrm{C}$ and $\mathrm{pH}$ value of $7 \pm 1$. Their thickness swelling and mass increasing rates of water absorption for $24 \mathrm{~h}$ were recorded, and results are shown in Table 10.

Table 10. Thickness Swelling and Mass Increase Rates due to Water Absorption by Different Samples

\begin{tabular}{|c|c|c|}
\hline $\begin{array}{c}\text { Modified lignin dosage } \\
(\%)\end{array}$ & $\begin{array}{c}\text { Thickness swelling rate } \\
(\%)\end{array}$ & $\begin{array}{c}\text { Mass increasing rate } \\
(\%)\end{array}$ \\
\hline 30 & 29.19 & 76.04 \\
\hline 40 & 34.06 & 74.44 \\
\hline 50 & 17.43 & 56.06 \\
\hline 70 & 8.50 & 41.78 \\
\hline
\end{tabular}

According to the data, those samples had high thickness swelling and mass increasing rates, but part of the reasons is that the composites were very thin. Compared with some $5 \mathrm{~mm}$ thick middle density fiberboard (MDF), which had a thickness swelling rate of $20 \%$ (Liu 2005), those samples made with $30 \%$ and $40 \%$ modified lignin had very high thickness swelling rates (around than 40\%) due to water absorption and also very high mass increasing rates of water absorption (greater than $70 \%$ ). With the increasing of modified lignin dosage, the composites had better anti-water absorption abilities. When the modified lignin dosage was $70 \%$, the composites had thickness swelling rates of $8.50 \%$, which is much lower than those of some MDF.

\section{Free Formaldehyde Content of the Composites}

The free formaldehyde content is a very important factor for wood-based composites. In this study, EH lignin was modified with formaldehyde, so it is reasonable to expect some free formaldehyde to be present in the lignin-based composites. Table 11 shows the free formaldehyde contents of the lignin-based composites. According to the data, the free formaldehyde contents of those lignin-based composite were 1.83 to $2.70 \mathrm{mg} / \mathrm{L}$, which indicates that they were low enough to meet Grade 2 in the national standard of China. 
Table 11. Free Formaldehyde Contents of the Lignin-based Composites

\begin{tabular}{|c|c|}
\hline $\begin{array}{c}\text { Modified lignin dosage } \\
(\%)\end{array}$ & $\begin{array}{c}\text { Free formaldehyde content } \\
\left(\mathrm{mg}^{-1}\right)\end{array}$ \\
\hline 30 & 2.70 \\
\hline 40 & 2.34 \\
\hline 50 & 2.31 \\
\hline 70 & 1.83 \\
\hline
\end{tabular}

\section{CONCLUSIONS}

1. Enzymatic hydrolysis (EH) lignin was used to prepare lignin-based composites successfully after being modified. First, the phenolic hydroxyl group content of EH lignin was analyzed, and the reactivity of the lignin was confirmed. Then, the lignin was modified with formaldehyde according to its phenol group content. TG-DSC and PY-GC-MS analysis methods were adopted to characterize the differences between EH lignin and the modified lignin. After that, the modified lignin was mixed with wood sawdust and made a lignin-based composite under the following conditions: pressure of 2 to $5 \mathrm{MPa}$, temperature of 175 to $190{ }^{\circ} \mathrm{C}$, and the modified lignin dosage of $20 \%$ to $70 \%$.

2. Some mechanical properties, anti-moisture water abilities, and free formaldehyde contents of the composites were tested. The effects of pressure, temperature, and the modified lignin dosage on the properties of the composites were also evaluated. Higher pressure and higher modified lignin dosage were very helpful to make strong composites. Temperatures of $175{ }^{\circ} \mathrm{C}$ and $190{ }^{\circ} \mathrm{C}$ did not make much difference to change the mechanical properties of the composites. The composites with higher dosage of modified lignin also had better abilities of anti-moisture and water. So, pressure and the ratio of modified lignin to sawdust are vital factors.

3. The composites which were made under $3 \mathrm{MPa}, 180^{\circ} \mathrm{C}$, and the ratio of $1: 1$ modified lignin to wood sawdust were of fair quality. Their bending strength was $23.35 \mathrm{MPa}$, and their elastic modulus was $3.78 \mathrm{GPa}$. For the samples made with the modified lignin dosage of $70 \%$ under $2 \mathrm{MPa}$ at $180^{\circ} \mathrm{C}$ for $10 \mathrm{~min}$, their thickness swelling rate of moisture absorption from air in $5 \mathrm{~d}$ was $2.92 \%$ and that of water absorption in $24 \mathrm{~h}$ was $8.50 \%$. The free formaldehyde content was around $1.83 \mathrm{mg} / \mathrm{L}$, which met Grade 2 in the national standard of China.

\section{ACKNOWLEDGMENTS}

This work was supported by the Fundamental Research Funds for the Central Universities ( No. DL09CB09). The authors are very grateful. 


\section{REFERENCES CITED}

Alonso, M. V., Rodríguez, J. J., Oliet, M., Rodríguez, F., García, J., and Gilarranz, M. A. (2001). "Characterization and structural modification of ammonic lignosulfonate by methylolation," Journal of Applied Polymer Science 82, 2661-2668.

Cheng, X., and Jin, Y. (2008). "Application of organosolv lignin in lignin modified polyurethane," Building Energy Efficency 7, 40-44.

Demirbas, A. (2007). "Progress and recent trends in biofuels," Progress in Energy and Combustion Sci. 33, 1-18.

Galbe, M., and Zacchi., G. (2002). "A review of the production of ethanol from softwood," Appl. Microbiol. Biotechnol. 59, 618-628.

Hahn-Hägerdal, B., Galbe, M., Gorwa-Grauslund, M. F., Lidén, G., and Zacchi, G. (2006). Bio-ethanol - the fuel of tomorrow from the residues of today. Trends Biotechnol. 22(12), 549-556.

Kleinert, M., and Barth, T. (2008). "Phenols from lignin," Chemical Engineering and Technol. 31(5), 736-745.

Lai, Y., Zhang, Z., Huang, G., and Chi, C. (2007). "Determination of the content of phenolic hydroxyl groups in lignin and pulp with FC-method," Transactions of China Pulp and Paper 22, 54-58.

Li, X., and Bai, B. (1997). Synthesis and Application of Artificial Board Adhesives, Northeast Forestry University Press, Harbin.

Liu, X. (2005). "Influence of testing condition on thickness swelling rate for wood-based panels," China Wood Industry 19(3), 31-33.

Malutan, T., Nicu, R., and Popa, V.I. (2008a). "Contribution to the study of hydroxymetylation reaction of alkali lignin," BioResources 3(1), 13-20.

Malutan, T., Nicu, R., and Popa, V.I. (2008b). "Lignin Modification by epoxidation," BioResources 3(4), 1371-1376.

Öhgren, K., Bura, R., Saddler, J., and Zacchi, G. (2007). "Effect of hemicellulose and lignin removal on enzymatic hydrolysis of steam pretreated corn stover," Bioresource Technol. 98, 2503-2510.

Sjöström, E. (1993). Wood Chemistry, Second Edition: Fundamentals and Applications, Academic Press, San Diego.

Sun, Y., and Cheng, J. (2002). "Hydrolysis of lignocellulosic materials for ethanol production: A review," Bioresource Technol. 83, 1-11.

Yang, S. (2006). Plant Fiber Chemistry. $3^{\text {rd }}$ Edition. Chinese Light Industry Publishing House, Beijing.

Zaldivar, J., Nielsen, J., and Olsson, L. (2001). "Fuel ethanol production from lignocellulose: A challenge for metabolic engineering and process integration," Appl. Microbiol. Biotechnol. 6, 17-34.

Zhou, M., Qiu, X., and Yang, D. (2009). "Preparation of water-soluble graft copolymer GCL3S from wheat straw soda lignin," Polym. Mat. Sci. Eng. (1), 145-148.

Article submitted: November 16, 2010; Peer review completed: February 26, 2011;

Revised version received and accepted: March 15, 2011; Published: March 17, 2011. 